\title{
Ethnologies
}

\section{Christie Davies. Jokes and Targets. (Bloomington: 2011, Indiana University Press. 328 pp. ISBN: 978-0-253-22302-9)}

\section{Molly McBride}

Volume 34, numéro 1-2, 2012

URI : https://id.erudit.org/iderudit/1026156ar

DOI : https://doi.org/10.7202/1026156ar

Aller au sommaire du numéro

Éditeur(s)

Association Canadienne d'Ethnologie et de Folklore

ISSN

1481-5974 (imprimé)

1708-0401 (numérique)

Découvrir la revue

Citer ce compte rendu

McBride, M. (2012). Compte rendu de [Christie Davies. Jokes and Targets.

(Bloomington: 2011, Indiana University Press. 328 pp. ISBN:

978-0-253-22302-9)]. Ethnologies, 34(1-2), 319-321.

https://doi.org/10.7202/1026156ar d'utilisation que vous pouvez consulter en ligne.

https://apropos.erudit.org/fr/usagers/politique-dutilisation/ 


\section{COMPTES-RENDUS / REVIEWS}

Christie Davies. Jokes and Targets. (Bloomington: 2011, Indiana University Press. 328 pp. ISBN: 978-0-253-22302-9)

In Jokes and Targets, Davies explains how certain joke cycles that have targets move throughout time and place. Specifically, as his title suggests, he explores how certain groups of people have become the targets of certain scripts. In considering jokes as social facts, Davies focuses on the social and political contexts that give jokes meaning in order to understand the nature of targets. His objective for this text, which becomes clear only in the conclusion, is to build upon and refine his previous models of jokes and their targets. Working towards a grand theory of jokes and targets, Davies asserts that his center-periphery model (1990), monopoly-competition model (2009), and mind-over-matter model further elucidated in this text should be used together to fully grasp the place of jokes in society.

The text is organized into six chapters that center on either a target or script that targets. The joke cycles, or themes, examined are: jokes about stupidity and canniness, libidinous blondes and French people, Jewish people, men's sexuality, American lawyers, and the Soviet Union. Jokes about the French, lawyers, and Jewish men and women are explained in terms of their historical and political contexts, whereas jokes for which there is no set target (for example those about stupidity) are explained by drawing connections between targeted groups. These differences in analytical approaches can at times obfuscate the purpose of the text, but the contrasts raise further questions that others can build upon.

Chapter One, "Mind Over Matter," groups stupidity jokes and canny jokes into one cycle based on the dichotomy between mind and body (47), intelligence and the material (67). This chapter covers extensive ground, discussing eight target groups, ranging from the militia to blondes. Readers gain a more generalized view of stupidity and canny joke scripts rather than the specific contexts of each target group. It is mainly this chapter on the mind-over-matter model that Davies connects to his previous work. 
Chapter Two begins with a brief examination of sex jokes about blondes and then focuses for the majority of the chapter on sex jokes about French people. The contextualization and analysis of French jokes is the strongest section of the book; the chapter would have more coherence if the section on blonde women was omitted. Davies concludes that while blonde jokes are not actually about blondes (they are about specific values of beauty), "French jokes are about the French" (112). This difference raises issues that scholars could pursue in the future: what types of meanings arise from contrasting jokes with set targets and joke scripts without set targets?

The rest of the book presents similar issues with different targets and scripts. Chapter Three delves into various joke scripts about Jewish femininity and masculinity that have been created and told both by Jewish and non-Jewish people. In Chapter Four Davies examines two types of joke scripts about men: intimacy in homosocial situations and homosexual or feminine men. Chapter Five examines the American lawyer joke cycle and ties its movement and meaning to the American political system. The final cycle Davies examines is Soviet Union jokes created by citizens to criticize the former state.

Because of the varying nature of scripts in each cycle, the organization of theoretical work can at times be confusing. Some chapters seem to be based on a target and the various scripts told about the target, such as the chapters on French people and lawyers; other chapters appear to focus on open-ended cycles that contain various scripts and targets within, such as Chapter One. The difference in argument organization within chapters can be disorienting; however, Davies provides excellent transitions between topics that allow for flow of ideas and engagement with text. Appropriately placed quips and a humorous tone also allow the reader to connect with the material.

Davies also provides a wealth of jokes in the text sourced from folklore archives and the Internet. Examples illustrate his arguments about specific targets, but also raise questions about how targets work within jokes. The position of "target" is not always clear; in particular, in those jokes where the main target is compared to another group, the compared group is also a target. For example, jokes that condemn men for being effeminate imply that femininity is not as valued as dominant conceptions of masculinity. The same could be said about stupidity jokes comparing a target with a group perceived to be in low-esteem. Examining the secondary or silent target is an area that could be expanded upon in the future. 
Throughout the text Davies asserts that jokes do not affect societies; they "are not a moral enterprise" (266). The most dramatic example appears in the chapter on Soviet jokes: "Ideologies kill. Jokes do not" (211). These contentious statements confront the reader with a serious question: do jokes only reflect contemporary socio-political conditions of a society, or do they also affect that society's conditions? Are the jokes that folklorists collect mere artifacts of culture or agents of culture? Davies firmly believes jokes do not affect society and is quick to dismiss those who consider jokes to have a constitutive power. His claim, however, is contradicted in the very examples provided in the text; jokes that cast homosexuality in a negative light, for example, perpetuate and reinforce dominant regimes of gender. These jokes are based on perceived incongruities of "moral" matters; judgment is not suspended (266), but makes the basis of the joke. The work of many scholars (Dundes 1987; Hengen 1998; Oring 2003; Gilbert 2004) illustrates the significance and consequence of jokes and humour, casting jokes in a much broader light than Davies' metaphor of jokes as thermometers. Davies further contradicts himself on the matter when he lists the ways in which he personally uses humour, providing examples of jokes used to make political statements (267).

Surely, jokes can be both thermometers and thermostats. Folklorists can expand upon Davies' work by continuing to study the specific contexts in which jokes are told to provide insight into how jokes are a part of ideology. Further, in analyzing these cycles as social facts, another productive question to ask is how the societies from which the cycles originate organize them as opposed to scholars' grouping of cycles. Though this text is somewhat disappointing in its organization of theoretical work, Davies continues to impress with the depth of his knowledge on jokes and targets.

Molly McBride

Memorial University

\section{References}

Dundes, Alan. 1987. Cracking Jokes: Stories of Sick Humor Cycles and Stereotypes. Berkeley: Ten Speed Press.

Gilbert, Joanne R. 2004. Performing Marginality: Humor, Gender, and Cultural Critique. Detroit: Wayne State UP.

Hengen, Shannon. (ed) 1998. Performing Gender and Comedy: Theories, Texts, and Contexts. Amsterdam: Gordon and Beach.

Oring, Elliot. 2003. Engaging Humor. Urbana: University of Illinois Press. 